\title{
CONFIRMING THE IDENTITY OF THE CIA-CIA LAPORO COMMUNITY THROUGH LOCAL LANGUAGES ON BUTON ISLAND SOUTHEAST SULAWESI
}

\author{
Hasrinando Saputra Laronga ${ }^{{ }^{*}}$, Citra Dewi ${ }^{1}$, Hapsa ${ }^{1}$ \\ ${ }^{1}$ Anthropology Study Program Tadulako University \\ Email: hasrinandolaronga@gmail.com
}

\begin{abstract}
Language is present as a medium to understand each other. However, for the Cia-Cia Laporo community, language is not only a means of communication but also as a medium to gain strength in asserting ethnic identity and as citizens of Laporo descent. This essay aims to describe and to know the position of language as a form of Cia-Cia Laporo's identity. Awareness of the importance of the regional language is then applied in daily life through formal learning methods in schools as well as various traditions and rituals such as sindighao. Keywords: Cia-Cia Laporo Language; Identity; Ethnic
\end{abstract}

\begin{abstract}
ABSTRAK
Bahasa hadir sebagai media untuk saling memahami antara satu dengan yang lainya. Namun demikian bagi masayarakat Cia-Cia Laporo bahasa tidak hanya sebagai alat komunikasi tetapi sekaligus sebagai media untuk meraih kekuatan dalam menegaskan identitas etnis maupun sebagai warga keturunan Laporo. Essay ini bertujuan untuk mendeskripsikan, serta mengetahui kedudukan bahasa sebagai bentuk identitas Cia-Cia Laporo, Kesadaran yang lahir dari masayarakat dalam menguhkan identitas tersebut mengharuskan mereka paham dan fasih menggunakan bahasa daerahnya, terlebih lagi ketika bahasa diyakini sebagai simbol keturunan Cia-Cia Laporo. Kesadaran akan pentingnya bahasa daerah tersebut selanjutnya diaplikasikan dalam kehidupan keseharian melalui metode pembelajaran formal disekolah serta berbagai tradisi dan ritual seperti siNdighao, Pomali dan berbagai macam tradisi yang masih dipertahankan oleh Etnis Cia-Cia Laporo, di Pulau Buton.
\end{abstract}

Kata Kunci: Bahasa Cia-Cia Laporo; Identitas; Etnik

Submisi: 3 Januari 2022

\section{Introduction}

Language Studies is a cultural phenomenon that is close to human life. These studies are associated with the same sign and are interchangeable (Anderson: 2008). Therefore, Kuntjara (2006) reveals that every society has and uses these symbols that can be used as signs, and one of the most powerful symbols in human life is language.

"Everyone knows this is a language. Because every element of life, language is evidence in balancing. Language is a symbol of Cia-Cia Laporo ethnic descent," said Amaenci, the traditional leader of the CiaCia Laporo ethnic group, is a former Waji of the community of Karya Baru Village, BauBau City, Southeast Sulawesi. Works as a farmer having his address at Jalan Axis BauBau -Pasarwajo. Currently, he is still active as a traditional leader of the Cia-Cia Laporo community. This understanding finally emerged after the problems of speakers of the language. Koentjaraningrat (2005:20) also stated more clearly regarding the language possessed by every human being from various colors of ethnic groups saying various colors of language. With the important position of language in life, language is considered the first reason to know more about the area (Faruk, 2007: 36). 
Another relationship related to language is power relations and more specifically related to historical power relations (Bordieu in Jenkins, 1992:154). This picture places language in its own position in social life. Anderson (2008:20) states that there is nothing in this world that does not have language, with language showing the status of its users and showing values in a society. So it is considered when using language is a symbol of existence.

The existence of language is a complement and perfection of culture, language is considered used to express an identity. As the Balinese language which reflects the Balinese people (Suastra: 2009). Schieffelin (2005:305) also explains that language as a study of socialization every child is emphasized to use language. Thus building a social paradigm that makes the claim that each socialization process is the most central and crucial dimension. Schieffelin (2005:305) in his research on Language Socialization explains that The language socialization paradigm addresses the lack of culture in language acquisition studies, and the absence of language in child socialization studies by insisting that in becoming competent members of their social groups, children are socialized through language, and they are socialized to use language. Hence, language is not just one dimension of the socialization process; it is the most central and crucial dimension of that process. The language socialization paradigm makes the strong claim that any study of socialization that does not document the role of language in the acquisition of cultural practices is not only incomplete.

In contrast to the various concepts stated above, for the Cia-Cia Laporo ethnic group, language does not only act as a means of communication, signs and symbols, forms of historical power, identity, and user status but also refers to language as a new form of power. Language acts as a forum to strengthen social position, so that it has an existence in establishing social relations, and continues to survive as an ethnic Cia-
Cia Laporo who lives in the midst of a large ethnic group called Wolio. Public awareness of the importance of regional languages as an identity as well as strengthening their social position has led to new methods in the process of internalizing and socializing regional languages that are different from others. Where language is not only present in traditions and rituals but language is inherited through intense socialization in the family and society with the reverse method. This means that the internalization of regional languages does not start from birth but through formal education in schools. Children from birth to school age are taught Indonesian as the state language, then at school age they are introduced to local languages. This method, by local residents, is called the reverse method because the introduction of language begins when children get to know formal education, not from birth. This reverse method is in accordance with the community's belief that the Cia-Cia Laporo language is born in every individual of Laporo descent. This means that the internalization of regional languages does not start from birth but through formal education in schools. Children from birth to school age are taught Indonesian as the state language, then at school age they are introduced to local languages. This method, by local residents, is called the reverse method because the introduction of language begins when children get to know formal education, not from birth. This reverse method is in accordance with the community's belief that the Cia-Cia Laporo language is born in every individual of Laporo descent. This means that the internalization of regional languages does not start from birth but through formal education in schools. Children from birth to school age are taught Indonesian as the state language, then at school age they are introduced to local languages. This method, by local residents, is called the reverse method because the introduction of language begins when children get to know formal education, not from birth. This reverse method is in 
accordance with the community's belief that the Cia-Cia Laporo language is born in every individual of Laporo descent. by local residents it is called the reverse method because the introduction of language begins when children get to know formal education, not from birth. This reverse method is in accordance with the community's belief that the Cia-Cia Laporo language is born in every individual of Laporo descent. by local residents it is called the reverse method because the introduction of language begins when children get to know formal education, not from birth. This reverse method is in accordance with the community's belief that the Cia-Cia Laporo language is born in every individual of Laporo descent.

From the description above, the focus of this research is how is the Cia-Cia Laporo language used as a forum to strengthen social position?

\section{Research Methode}

This research is a qualitative research. To obtain various data and information needed, the data was collected through library research and field research which included observation and interviews. The interview method was carried out in two ways, namely structured interviews using interview guidelines and unstructured interviews. Informants were selected through the snowball technique. This research was conducted in the last months of 2020 to be precise from November to December. The research location is in Southeast Sulawesi Province, Bau-Bau City, Sorawolio District, Karya Baru Village. I chose this place because this village is one of the villages that preserves the Cia-Cia Laporo language and is the closest village to the Buton Sultanate area which uses the Wolio language.

\section{Results And Discussion Cia-Cia Laporo Community Life}

Collectively, the Cia-Cia Laporo community is formed from a large ethnic group called Cia-Cia. This ethnicity is an ethnic group that lives in the Buton Island area. The Cia-Cia ethnicity is spread across the Buton and Wakatobi Islands. The CiaCia ethnic group is one of the ethnic groups who inhabit the Buton Island area. Consists of various types of sub-ethnic. Such as CiaCia Laporo, Cia-Cia Sampolawa, Cia-Cia Wabula, Cia-Cia Lapandewa, Cia-Cia Batauga, Cia-Cia Wacuata, and Cia-Cia Wali. This ethnicity is spread throughout the Buton and Wakatobi islands. The cooperative system is adopted by the residents of Cia-Cia Laporo, so that various types of activities always involve the local community. The origin of the word Laporo comes from the word "mia Momaporona yincana" which means people who are sad. Based on folklore, the community has other opinions regarding the origin of the name of the laporo tribe such as "sangia goa a laporo yi raja" which means sangia goa reported its findings to the king or sultan of Buton at that time (Jurumai: 2008: 60).

In 1968, the residents of Cia-Cia Laporo migrated from the cool mountain to an area called Karyabaru. This is based on the expansion of the territory of the kingdom of Wolio and the territory of the Sultanate of Buton. This migration was carried out twice. First, the male population started clearing land and planting crops in the area. Thus, in 1968 the Karyabaru area was only considered a plantation by the residents. Two years later, a second migration took place, moving women and children to live together in the new area. Thus, a new village was born which in the early 2000s had become the definitive area of Bau-Bau City to become Karyabaru Village.

Geertz (1992) explains that human efforts in placing themselves in their customs and traditions have a very close relationship with all the structures of life. So, people who still hold fast to their traditions are very pronounced and try not to miss any of these stages. Applicable norms and laws of Pomali (means taboo in the Cia-Cia Laporo society) which is still developing into a key citizen still holds tightly to the traditions they have. These mystical powers 
are believed to return to them when they make a mistake.

\section{Language as a symbol of Cia-Cia Laporo's Descendants}

Language is an important component in human life, apart from being a communication tool, it also acts as a symbol of identity and strength of ethnic groups. This phenomenon will see language as a cultural system that focuses on the position of the Cia-Cia language as the Cia-Cia Laporo ethnic identity. This means that the meaning carried out in maintaining the position becomes a great awareness among group members to maintain the continuity of the Cia-Cia Laporo language. Finally, we will see how far language can be maintained and become a symbolic thing in the lives of the Cia-Cia Laporo ethnic community members.

Bordieu argues that language is part of the way of life of a social group and essentially provides services for the achievement of practical goals (Richard Harker, et al, 2009). The life of the Cia-Cia Laporo community which cannot be separated from their relationship with their customs and traditions is a strong evidence of the position of language in the life of the Cia-Cia Laporo Community. Roles are often only used as material for interaction or communication tools. However, there are other views that actually consider this language as a form of identity as well as a form of proof of descent.

Since the first time residents began to settle in the Karyabaru area, residents have been familiar with the structure of traditional institutions. This traditional institution acts as a regulator and balancer for the social life of the Cia-Cia Laporo community. In daily activities, language has an important role both in traditions and rituals, communication tools as well as as a symbol of descent and non-genealogical identity of the Cia-Cia Laporo community. There are several traditions found in Karyabaru Village, including, Mata'a, Sindighao, and Mass Circumcision. For example, in the sindighao tradition, verbal expressions of sarcasm are often used by young people to attract the attention of the parents present at the meeting. Young people become very meaningful when they are able and able to perform Sindighao in front of traditional gatherings. This tradition is usually done when going to start a big meeting such as Batanda'a, or opening plantation land owned by residents. All these expressions are spoken in the Cia-Cia Laporo language.

The use of the Cia-Cia Laporo language is also a must for citizens to interact. Intense socialization in the family is the most effective learning media. However, every child born is always taught to use Indonesian as the state language. The community believes that the Cia-Cia Laporo language will grow and be born in every Cia-Cia Laporo descendant over time. The Cia-Cia Laporo language is a symbol of the descendants of the Cia-Cia Laporo people, according to a Parabela, a traditional head of the Cia-Cia Laporo ethnic group. In the traditional institutions of the Cia-Cia Laporo community, recognize the traditional apparatus with the name Parabela as the customary head, Moji as Parabela's companion in traditional events, Waci the traditional apparatus who has a role as minister in the government structure, Pandesuka as a healer or shaman and Kolaki as a traditional instrument that have a relationship with the supernatural., not genealogically, but as a symbol of individual involvement in every customary activity and various sacred rituals. Proficiency in using the local language is one of the prerequisites for everyone who wants to be involved, for example, if someone wants to sit in the same place in the ceremony, it is necessary to use the local language as a means of communication with their ancestors.

\section{Language as a Form of Identity}

Carrying out its role as a symbol of descent, the Cia-Cia Laporo language is a testament to the strength of the Cia-Cia Laporo group on Buton Island. Keating and Egbert (In Durtin 2004:170) explain that 
how the study of language use builds or reconstructs social actors with certain activities, socializes new members of society, builds and opposes authority, measures hierarchies and produces multiple identities. So that makes this condition more maintain the group they have.

Language was then born to answer the problems that exist in the region. As Bordieu (1990) argues, language reflects the reality of being in control over the centuries and consistently functioning as a justification for political power. This is based on the change in the curriculum for learning local content from the Cia-Cia regional language to the Buton Wolio language, causing the community's struggle to be even greater to maintain the language.

The use of local languages in daily interactions is one of the efforts to keep local languages afloat in a society that continues to change. In addition, through language, ethnic identity is rebuilt by the Cia-Cia Reporto ethnicity by presenting an ideological spirit in accordance with the traditions of their ancestors. at this stage language is not only seen as a communication tool but also as an important component of social balance as well as a problem solving tool when the community begins to realize that there is great power to be gained if the Cia-Cia Laporo regional language is seen as an ethnic identity. Therefore, at the same time, language is seen as a power to assert identity, tradition and communication. the third is a way of explaining the answers to language problems, especially the use of regional languages which have recently begun to be abandoned by the younger generation. Through these efforts, the method of strengthening the language by applying characters to the language is important. So, when using language as a symbol of descent or ethnic identity, it has a strong foundation, especially related to ancestral traditions passed down from generation to generation through language.

The same situation is also described in Kang's (2006) research that the identity status of the Petalangan community in Pekanbaru is built on the basis of their traditions. So placing the rituals they do is a symbol of their identity to outsiders. Where tradition is a benchmark in maintaining the identity of a community group. Naturally, people have the instinct to maintain their identity status. As the people of Cia-Cia Laporo, who have a new awareness of the importance of using local languages as well as the use of letters that are acceptable among the wider community and especially the younger generation as owners and successors of identity.

Language which then becomes a symbol of identity confirms to the outside world a form of existence. In its implementation, the Cia-Cia Laporo language is a symbol of the descendants of the Cia-Cia Laporo community, which proves the existence of those who live in the midst of the Wolio ethnic territory. The language of the Cia-Cia Laporo ethnic group is used as a form of their existence and connecting them with their ancestors, as well as making language a form of strength for a group.

\section{Cia-Cia Laporo Language Learning Method}

Since a baby is born from the Cia-Cia Laporo family, the power of teaching is carried out entirely by the parents. In the Cia-Cia Laporo community, educating children is entirely done by a mother. So that mothers are required to be able to use Indonesian language fluently as well as speak Cia-Cia Laporo as well. This task is carried out by a mother because the community believes that it is women who are in control of all household activities who intensively meet and engage in many activities with children as well as caregivers for the Cia-Cia Laporo family.

The language status was changed by the customary government as a form of group identity, then continued with efforts to create a model for teaching regional languages that was carried out differently by the Cia-Cia Laporo ethnic group. At a young 
age, society gives them the freedom to use Indonesian. Indonesian is a language that is also considered very important because it will be used when they are going to school. In these early days the mother will be very instrumental, because the mother will spend the day with the child. Furthermore, when children get to know the world of school, then children are taught to use the local language. Various facilities were then arranged as supporting tools for this learning process including school books which were translated into Cia-Cia Laporo language.

In addition to the learning methods taught to children through formal education, children are also introduced to tradition as a means of language socialization. For example, when children grow up, children will be faced with a tradition of mass circumcision which makes them the main actors in the tradition. So that the children will get used to using the Cia-Cia Laporo language. Mass circumcision is a circumcision performed by Cia-Cia laporo children as a form of child maturity and towards reaching puberty. Usually this circumcision is carried out once a year and gathers all the children of Cia-Cia Laporo to perform the circumcision together since they were taken by a lebe (substitute for the birth mother in the circumcision ritual) until they were brought to limbo (where the circumcision ritual is performed) all the children became the main actors

To maintain it all, the customary government uses script in the use of their language. Until now, the characters continue to be used by the children of Cia-Cia laporo. The characters used are Hangeul from korea (The traditional institution agreed to use the Korean script, namely Hangeul, to be used as a form of writing the Cia-Cia Laporo language. This is to suppress the extinction of the language that is being experienced by the Cia-Cia Laporo group due to the progress of the era). This is to maintain the continuity of the language to be always spoken by the speakers.

\section{Conclusion}

The Cia-Cia Laporo community generally uses the Cia-Cia Laporo language as a means of communication between group members. However, language is considered sacred because of its nature which is present in every community tradition. Because language appears in tradition, the Cia-Cia Laporo language is considered a form of existence and identity for the Cia-Cia Laporo people. as a form of existence, the Cia-Cia Laporo language becomes a part of the life of the Cia-Cia Laporo community. To emphasize this, language is always present to connect them with their ancestors. Such as Sindighao (satire), Mata'a (Harvest Party), mass circumcision and others.

Understanding of language is also considered as a symbol of the descendants of the Cia-Cia Laporo people who are considered to be born naturally for the people of Laporo descent. It is believed that the Cia-Cia Laporo language must have been understood by the Laporo descendants. The cultural diversity possessed by the CiaCia Laporo ethnic group is one of the fundamental reasons why this tradition must still be maintained. Efforts to maintain the Cia-Cia Laporo language are then applied in daily life, including in traditional institutions that are believed to be the regulators of social life, various traditions and rituals as well as formal learning in schools.

\section{Referensi}

Anderson, Benedict, 2008, diterjemahnkan oleh Omi Intan Naomi, Imagined communities: Komunitas-Komunitas Berbayang, Yogyakarta, Insist Press bekerja sama dengan Pustaka Pelajar.

Durtin, Alesandro, 2004 A companion to Linguistic Anthropology, Black Well Pblished Ltd, UK

Faruk, 2007, Belenggu Pasca-Kolonial Hegemoni dan Resistensi dalam Sastra Indonesia, Pustaka Pelajar, Yogyakarta 
Geertz, Clifford, 1992, Tafsir Kebudayaan, Penerbit Kanisius (Anggota IKAPI), Yogyakarta

Harker, Richard, Cheleen Mahar, Chris Wilkes, 2009, (Habitus x Modal)+ Ranah=Praktik, Pengantar paling Komerhensif keada Pemikiran Bourdieu, JALASUTRA Anggota IKAPI, Yogyakarta

Jenkins, Richrard, 1992, Pierre Bordeu (Key Sociologist), London, Routledge Publisher

Jurumai, La Pande, 2018, Umangano Ompu Sebagai Kesadaran Transendental Tata Ruang Permukiman Desa Dan Tata Ruang Rumah Tradisional Suku Cia-Cia Laporo Desa Gunung Sejuk, Universtas Gadjah Mada, Tesis, Koleksi Pribadi

Kang, Yoonhee , 2006, "Staged" Rituals and "Veiled" Spells: Multiple Language Ideologies and Transformations in Petalangan Verbal Magic Journal of Linguistic Anthropology, Vol. 16, Issue 1, pp. 122, ISSN 1055-1360, electronic ISSN 1548-1395.

American Anthropological Association. All rights reserved. UNIVERSITY OF PENNSYLVANIA

Koentjaraningrat, 2005, Pengantar Antropologi II, Jakarta: Rineka Cipta

Kuntjara, Esther, 2006 Penelitian Kebudayaan Sebuah Penelitian Praktis, Yogyakarta, Graha ilmu

Suastra, I Made, 2009, Bahasa Bali sebagai Simbol Identitas Manusia Bali, Linguistika: Buletin Ilmiah Program Magister Linguistik Universitas Udayana, (S1), V. 16. Maret, 2009 ISSN 2656-6419 